\title{
Empathy in teaching foreign languages in a distance format at universities
}

\author{
Svetlana Yurievna Dronova ${ }^{1}$, and Ainur Durbelenovna Kurmangalieva ${ }^{2}$ \\ ${ }^{1}$ Financial University under the Government of the Russian Federation, Department of Foreign \\ Languages and Intercultural Communication, Department of Political Science, Moscow, Russia \\ ${ }^{2}$ Al-Farabi Kazakh National University, Department of Philosophy and Religious Studies, Alma-Ata, \\ Kazakhstan
}

\begin{abstract}
Empathy is a key factor in teaching foreign languages, making it possible to establish an emotional connection both between the teacher and students and between students themselves, as well as between students and a target language, which has a positive effect on learning outcomes. The distance learning format is no exception, but it requires more attention to this factor, since there are objective obstacles to the emergence of empathy in a natural way, which often occurs in face-to-face training and requires certain awareness when it is introduced into the educational process by the teacher. The research purpose is to develop practical recommendations for language teachers at universities on the introduction of psychological-methodological elements that contribute to an increase in the empathy of all participants in distance and hybrid classes to improve the effectiveness of learning. The research methodology includes an experiment, observation, deduction, survey, post-analysis. As a result of the study, specific recommendations were formulated to build an emotional connection in distance classes in a foreign language. Thus, it is recommended to use methodological and psychological tools, gamification, and discussion format of classes, to control the dynamics of seminars. Establishing an empathic connection is facilitated by less formal and more benevolent communication at distance seminars, preferably a targeted appeal to students, to the whole group, keeping the camera on and enriching seminars with various emotionally charged and substantive elements, the teacher's active presence in social networks during off-hours, engaging all types of work in real time: interactive whiteboard, editing shared documents.
\end{abstract}

Keywords: teaching foreign languages, empathy, pedagogy, teaching methods

\section{Introduction}

The coronavirus pandemic has forced educational institutions and educators to take a fresh look at both full-time, distance and hybrid education. In addition to the learning format, the teacher's role has also changed in many aspects of the educational process [1]. In modern foreign language teaching, it is necessary to take into account several main aspects: active 
learning, motivation, feedback [2], the development of communicative competence [3, 4] and the interdisciplinary nature of modern education [5]. However, the most important challenge in these conditions, often due to the lack of a common physical educational space, is to build a stable teacher-student relationship [6]. The formation of this connection, as well as an increase in the effectiveness of classes, should be facilitated by the inclusion of an element of empathy in the educational material and teaching practice [7].

Empathy is considered one of the teacher's key characteristics, since it allows establishing an adequate dialogue and ensuring cooperation of all participants in the educational process [8]. The concept of empathy involves understanding the emotions of another person [9], the ability to put oneself in his/her shoes [10] and consists of two components: cognitive and affective ones.

Studies also show that the teacher's empathy affects the level of students' motivation to learn foreign languages in a distance learning format [11-13]. The level of students' empathy to the teacher can positively affect their progress in learning foreign languages [14]. The more empathy and collaboration arise between teacher and student, the higher the level of satisfaction, enthusiasm and interest in the subject [15]. Empathy can create a calm and friendly classroom atmosphere and students will be more willing to learn a new language [16].

However, despite a wide body of research on the influence of emotions and empathy on teaching foreign languages, there is a noticeable lack of practice-oriented research aimed at developing specific recommendations.

The research purpose is to develop practical recommendations for language teachers at universities on the introduction of psychological and methodological elements that contribute to an increase in the empathy of all participants in distance and hybrid classes to improve the effectiveness of learning. Research objectives are to identify the factors and tools affecting the empathy of participants in the educational process, determine the central and most effective tools, formulate recommendations for teachers on their basis on increasing empathy and introducing the emotional component into the process of teaching foreign languages at universities.

\section{$2 \quad$ Methods}

The study was based on an experiment, observation, deduction, and survey. During the experiment, for 14 months (2020-2021), elements that were supposed to increase empathy when learning foreign languages were introduced into seminars for 1st-3rd year undergraduates on the subject "Second Foreign Language (Spanish)" studying at the Financial University under the Government of the Russian Federation in distance and hybrid formats. The elements were selected based on the researcher's experience, observation and deduction. At the end of the seminars, students were asked to express their emotions in relation to the introduced elements or the material in which they were used orally or in the form of an anonymous snap poll. The seminars were followed by a detailed post-analysis with the identification of effective practices, which were subsequently refined and retested. As a result, a list of the 15 most effective psychological and methodological techniques was formed. This list formed the basis for a survey of 203 students of all courses at all levels of education from 17 universities, who studied fully or partially in a distance format, in order to identify the most effective ones in students' opinion. On the basis of the survey, a list of recommendations for language teachers' practical activities at universities was made. 


\section{$3 \quad$ Results}

Table 1 shows the identified psychological and methodological tools in descending order according to the results of student surveys. The first column shows the percentage of students who voted for the effectiveness of this technique, while students could choose an unlimited number of points. It should be noted that all the practices identified during the first part of the study were assessed as effective.

Table 1. Recommendations for increasing empathy in distance learning of foreign languages at a university, based on survey materials.

\begin{tabular}{|c|c|c|}
\hline $\begin{array}{l}\text { Students who } \\
\text { voted, } \%\end{array}$ & Empathy tool in class & Recommendations for teachers \\
\hline 68 & $\begin{array}{l}\text { Humor regarding the } \\
\text { distance learning attributes }\end{array}$ & $\begin{array}{l}\text { You should not treat non-standard situations } \\
\text { arising in distance learning as a violation of } \\
\text { discipline, humor can help in establishing } \\
\text { empathic connections and motivate students to } \\
\text { study the subject. }\end{array}$ \\
\hline 63.1 & $\begin{array}{l}\text { Interactive real-time games } \\
\text { (kahoot, quizlet, menti, etc.) }\end{array}$ & $\begin{array}{l}\text { The use of gamification elements on various } \\
\text { topics: both lexico-grammatical and } \\
\text { country-specific ones. }\end{array}$ \\
\hline 56.2 & $\begin{array}{l}\text { Less formal communication } \\
\text { between the teacher and } \\
\text { students (compared to } \\
\text { face-to-face communication } \\
\text { in the classroom) }\end{array}$ & $\begin{array}{l}\text { It is recommended to avoid harshness and take } \\
\text { into account what words and actions in a } \\
\text { distance format, somewhat distorting } \\
\text { communication, may cause misunderstanding } \\
\text { and, as a result, students' frustration [17]. It is } \\
\text { necessary to more clearly formulate objectives } \\
\text { and provide explanations, show emotional } \\
\text { closeness with students and promote } \\
\text { cooperation. }\end{array}$ \\
\hline 53.7 & $\begin{array}{l}\text { Frequent change of activities, } \\
\text { dynamism of a seminar }\end{array}$ & $\begin{array}{l}\text { It is recommended to enrich distance seminars } \\
\text { with different forms of work within the } \\
\text { framework of the educational goal and control } \\
\text { the change of activities in time, so that } \\
\text { students' attention is not scattered and the } \\
\text { training retains its immersiveness, thereby } \\
\text { maintaining an empathic connection. }\end{array}$ \\
\hline 52.2 & Teacher's camera on & $\begin{array}{l}\text { Before classes, you should check that the } \\
\text { camera is working properly, lighting is } \\
\text { sufficient (do not sit with your back against } \\
\text { the window or other light source so that } \\
\text { students can see your face), show your face in } \\
\text { full, not part of it, and look directly into the } \\
\text { camera as often as possible. }\end{array}$ \\
\hline 50.7 & $\begin{array}{l}\text { Discussions both in a general } \\
\text { videoconference and in } \\
\text { separate working } \\
\text { conferences }\end{array}$ & $\begin{array}{l}\text { Discussions on the outlined topics contribute } \\
\text { to collaboration, which increases emotional } \\
\text { connection. }\end{array}$ \\
\hline 47.3 & $\begin{array}{l}\text { Teacher's active presence in } \\
\text { social networks and } \\
\text { communication with students } \\
\text { during off-hours }\end{array}$ & $\begin{array}{l}\text { It is recommended to create common } \\
\text { dialogues with students on social networks, } \\
\text { promptly answer questions, send visual } \\
\text { material not only to consolidate relevant } \\
\text { educational material, but also to get }\end{array}$ \\
\hline
\end{tabular}




\begin{tabular}{|c|c|c|}
\hline & & $\begin{array}{l}\text { acquainted with the culture, traditions and } \\
\text { modernity of target-language countries. }\end{array}$ \\
\hline 43.8 & Interactive whiteboard & $\begin{array}{l}\text { Both the teacher and students can have access } \\
\text { to the interactive whiteboard. Creative } \\
\text { collaborative tasks are recommended. }\end{array}$ \\
\hline 40.9 & $\begin{array}{l}\text { Real-time surveys and voting } \\
\text { (google forms, vk, ms teams, } \\
\text { etc.) }\end{array}$ & $\begin{array}{l}\text { Using voting tools to get feedback, select } \\
\text { topics for discussion, task types, etc., as a tool } \\
\text { to involve students in the organization of } \\
\text { training. }\end{array}$ \\
\hline 39.4 & $\begin{array}{l}\text { The teacher should address } \\
\text { the student, not the whole } \\
\text { group; personal comments } \\
\text { are recommended. }\end{array}$ & $\begin{array}{l}\text { Due to the lack of a common physical space, } \\
\text { the concept of a "study group" becomes } \\
\text { blurred, and therefore it is recommended to } \\
\text { address some of the students and then involve } \\
\text { others in the discussion, give feedback as } \\
\text { often as possible. }\end{array}$ \\
\hline 35 & Students' cameras on & $\begin{array}{l}\text { Asking students to keep their cameras on } \\
\text { should not be imperative at training seminars, } \\
\text { not control ones, however, you can introduce } \\
\text { the "rule of five cameras", where students } \\
\text { decide in advance who switches on the } \\
\text { cameras, this will help avoid embarrassing } \\
\text { situations and allow using all the } \\
\text { psychological and emotional advantages of } \\
\text { this tool. }\end{array}$ \\
\hline 31.5 & $\begin{array}{l}\text { Editing a shared document in } \\
\text { real time }\end{array}$ & $\begin{array}{l}\text { Organization of work on a shared document, } \\
\text { which structure or specific template is } \\
\text { emotionally charged (idioms, pictures, } \\
\text { puzzles, etc.). }\end{array}$ \\
\hline 26.6 & $\begin{array}{l}\text { Home comfort in the video } \\
\text { against the background: } \\
\text { interior, paintings, books, } \\
\text { things, pets (not a blurred } \\
\text { background or the } \\
\text { background replaced with a } \\
\text { neutral one) }\end{array}$ & $\begin{array}{l}\text { It is necessary to think ahead the position of } \\
\text { the teacher's camera and the background so } \\
\text { that it shows his/her interests or an interior } \\
\text { element. However, in some situations, } \\
\text { replacing the background with emotionally } \\
\text { charged and meaningful ones can serve a } \\
\text { pedagogical goal. }\end{array}$ \\
\hline 25.1 & $\begin{array}{l}\text { More time to discuss abstract } \\
\text { topics at the beginning of the } \\
\text { lesson. }\end{array}$ & $\begin{array}{l}\text { In distance learning, it is recommended to pay } \\
\text { special attention to "warming up" and "tuning } \\
\text { up" before starting the lesson to establish an } \\
\text { emotional connection and create the right } \\
\text { atmosphere; do not start the lesson right away } \\
\text { by checking homework or explaining new } \\
\text { material. }\end{array}$ \\
\hline 24.1 & $\begin{array}{l}\text { The use of videos and audio } \\
\text { recordings }\end{array}$ & $\begin{array}{l}\text { Video and audio materials in learning foreign } \\
\text { languages are an important source of } \\
\text { knowledge; they also help to create an } \\
\text { emotionally charged visual picture. }\end{array}$ \\
\hline
\end{tabular}

Thus, the presented tools are only an outer envelope, a carrier of the emotional part of information, while the recommendations indicate the content to be conveyed through these carriers, or a method of implementation.

\section{Discussion}


The results obtained show the possibility and effectiveness of introducing empathy in the distance learning of foreign languages at universities. Many of these recommendations have been mentioned in earlier studies. Thus, humor has a positive effect on the material assimilation, especially in foreign language classes [18, 19]. Researchers also come to conclusions about the important role of interactive games like Kahoot, Menti, Quizlet in bringing together the team of students based on the emotional factor, adding dynamics to studying a subject and elements of competition in distance and face-to-face training [20, 21]. According to a UNESCO study [22], students expect support from teachers in a difficult epidemiological situation that has forced the mass introduction of distance learning, which also affects the emergence of a desire for more informal and less strict communication in distance classes.

\section{Conclusion}

Empathy plays a key role in learning foreign languages in a distance format at the university. At first glance, this learning format suggests less involvement of emotions and empathy than face-to-face training, but when learning foreign languages, it is necessary to pay special attention to creating and maintaining empathy for effective material assimilation. Obviously, a teacher should use not only methodological, but also psychological tools in order to build and maintain an empathic connection in distance learning. Many of the recommendations considered are relevant both for distance learning and face-to-face training, such as gamification, discussion, dynamism. Building an empathic connection is facilitated by less formal communication in distance seminars, as well as keeping the camera on and enriching seminars with various emotionally charged and meaningful elements. A constant post-analysis of the conducted classes is required to identify the most effective practices for each group, maintain discipline and work on shortcomings.

The presented study can be continued by studying the possibilities of various computer programs and technologies, including immersive learning technologies, in terms of increasing students' empathy and, as a consequence, improving the efficiency of the educational process.

\section{References}

1. S. Bennett, L. Lockyer, Edu Media Int, 41(3), 231-248 (2004). https://doi.org/10.1080/09523980410001680842

2. I. Yengin, D. Karahoca, A. Karahoca, A. Yücel, Proc Soc Behav Sci, 2, 5775-5787 (2010). https://doi.org/10.1016/j.sbspro.2010.03.942

3. I.I. Klimova, G.V. Klimova, S.A. Dubinka, XLinguae, 12(1), 207-218 (2019)

4. I.I. Klimova, N.E. Sharabarina, E.A. Tikhova, S.A. Dubinka, XLinguae, 11(1XL), 67-74 (2018)

5. T.A. Goroshnikova, E.S. Smakhtin Interdisciplinary Curriculum Approach as a University Component for Large-scale Education Projects, Proceedings of 2018 11th International Conference; Management of Large-Scale System Development, MLSD (2018) https://doi.org/10.1109/MLSD.2018.8551932

6. O. Khatsrinova, V. Bronskaya, S.V. Barabanova, et al., Teacher Readiness for Distance Learning, in M.E. Auer, T. Rüütmann (eds), Educating Engineers for Future Industrial 
Revolutions. ICL 2020. Advances in Intelligent Systems and Computing, 1329, 453-469 (Springer, Cham, 2021). https://doi.org/10.1007/978-3-030-68201-9_45

7. D.S. Melo-Solarte, P.A. Díaz, Inf Tecnol, 29(3), 237-248 (2018). http://dx.doi.org/10.4067/S0718-07642018000300237

8. S. Stojiljković, G. Djigić, B. Zlatković, Proc - Soc Behav Sci, 69, 960-966 (2012). https://doi.org/10.1016/j.sbspro.2012.12.021

9. M. Davis, JSAS Catalog Sel Doc Psy, 10, 85 (1980)

10. S. Baron-Cohen, S. Wheelwright, J Autism Devel Disord, 34, 163-175 (2004). https://doi.org/10.1023/B:JADD.0000022607.19833.00

11. F.G. Escobar Fandiño, A.J. Silva Velandia, Heliyon, 6(8), E04630 (2020). https://doi.org/10.1016/j.heliyon.2020.e04630

12. S. Meyers, K. Rowell, M. Wells, B.C. Smith, College Teach, 67(3), 160-168 (2019). https://doi.org/10.1080/87567555.2019.1579699

13. T.M. Makoelle, Teacher Empathy: A Prerequisite for an Inclusive Classroom, in Peters M. (ed), Encyclopedia of Teacher Education. (Springer, Singapore, 2019). https://doi.org/10.1007/978-981-13-1179-6_43-1

14. Y. Hao, Comp Human Behav, 59, 295-303 (2016). https://doi.org/10.1016/j.chb.2016.01.031

15. D. Goleman, Inteligencia Emocional. (Editorial Kairós, Barcelona, 1997)

16. H. Gardner, Estructuras de la mente. Inteligencias multiples. (FCE, Santafé de Bogotá, 2001)

17. F. Borges, Digithum, 7(7), (2005). http://dx.doi.org/10.7238/issn.1575-2275

18. S. Bolkan, D. J. Griffin, A. K. Goodboy, Comm Edu, 67(2), 144-164 (2018). https://doi.org/10.1080/03634523.2017.1413199

19. M. Azizinezhad, M. Hashemi, Proc - Soc Behav Sci, 30, 2093-2098 (2011). https://doi.org/10.1016/j.sbspro.2011.10.407

20. K.E. Cameron, L.A. Bizo, Resn Learn Techn, 27, (2019). https://doi.org/10.25304/rlt.v27.2225

21. M. Curto Prieto, L. Orcos Palma, P.J. Blázquez Tobías, F.J.M. León, Edu Sci, 9(1), 51-56 (2019). https://doi.org/10.3390/educsci9010055

22. S. Duggan, AI in Education: Change at the Speed of Learning. (UNESCO IITE Policy Brief, 2020) 